\title{
ESTIMATION OF CELL SURVIVAL AFTER TRANSFUSION BY SELECTIVE AGGLUTINATION
}

\author{
By DOROTHY E. OSBORNE AND ORVILLE. F. DENSTEDT
}

(From the Department of Biochemistry, McGill University, Montreal, Canada)

(Received for publication August 31, 1946)

Selective agglutination, as a means of estimating the number of donor's erythrocytes in the circulation of a recipient after transfusion, was used first by Ashby (1) in 1919. In the procedure, groupO blood was administered to a subject of group A (or B), and in blood specimens taken periodically thereafter, the number of surviving donor-cells was estimated by selectively agglutinating those of the recipient with anti-A (or anti-B) serum, and. counting the unagglutinated group- $\mathrm{O}$ cells in a hemocytometer. Wiener and Schaefer $(2,3)$, in 1939 , obtained the same result by using the $M$ and $\mathrm{N}$ blood types. More recently still Wiener (16), and Mollison (4) have extended the technique to the $\mathrm{Rh}$ blood types using $\mathrm{Rh}$-negative donors and $\mathrm{Rh}$-positive recipients with anti-Rh as the agglutinating serum. Wiener and Peters (5), and Mollison and Young (6) have demonstrated the adaptability of the method by following the survival of 2 donors' cells simultaneously in the same recipient. The results obtained by these techniques are in good agreement, and show that if fresh blood is used for transfusion the donor's erythrocytes disappear from the recipient's circulation at the rate of about 1 per cent per day, which is the normal rate of red cell destruction. In the past 8 years the method has proved to be of great value in studies on blood preservation, particularly in testing the effects of various methods of preservation on the viability of erythrocytes during storage. From the practical standpoint, the $\mathrm{O}$ and $A$ blood groups offer the advantage that they occur frequently in the population and that highly potent anti-A serum is readily obtainable.

The original agglutination procedure of Ashby has been modified in various laboratories with regard to the amounts of cell suspension and antiserum used, temperature conditions, and technique. Numerous workers $(1,3,7,8,9,10)$ perform the reaction in small serological test tubes with or without agitation. Maizels and Paterson (11) use small beakers, and Loutit (12), small bottles with a relatively small amount of antiserum. Thalhimer (13) has reduced the number of manipulations to a minimum by carrying out the reaction in a red-cell pipette. The present authors have modified their former method by using light centrifugation to accelerate agglutination. This treatment is also a feature of the method of Dacie and Mollison except in the use of anti-M and anti-N sera (14) which are said to give some non-specific agglutination with centrifugation. All these procedures are based on extensive experimentation and, in the hands of experienced workers, give comparable results.

In determining the number of the donor's erythrocytes in the recipient's circulation by selective agglutination, it is necessary beforehand to know the recipient's "free" or "unagglutinable" cell count. In other words since complete agglutination of erythrocytes is impossible by ordinary methods the number of unagglutinable cells per $\mathrm{mm}^{3}$ must be ascertained prior to transfusion. The number of donor's cells in the post-transfusion samples may be determined by subtracting the recipient's free-cell count from the total number per $\mathrm{mm}^{3}$ Experience has shown that the free-cell count of the individual is fairly constant with a given potent antiserum, but it may vary with different antisera depending largely on the agglutinin potency, or titre. Authorities are agreed that strong antiserum is essential for accurate results. The consensus is that an antiserum for selective agglutination tests should be specific for the recipient's red cells and should give a free-cell count not exceeding 50,000 per $\mathrm{mm}^{3}$ of blood.

From time to time the reliability of the selective agglutination method has been queried. The various criticisms and their refutation have been discussed by Maizels and Paterson (11) and by Mollison and Young (15).

The study reported in the present paper arose from certain anomalies observed in an earlier investigation on red cell survival carried on during 
1940 to 1943. At that time we were using the method of Wiener and Schaefer (3) with anti-M and anti- $\mathrm{N}$ sera prepared in our laboratory according to the methods of Wiener (16) and of Davidsohn and Rosenfeld (17). The antisera, which were prepared aseptically, were potent and highly specific. Prior to use, the serum for a complete experiment was given an additional absorption with a light suspension of saline-washed red cells of the prospective recipient to ensure the absence of nonspecific agglutinins. Frequently, the serum, if strong, was diluted further before dispensing it into small serological tubes. The latter then were stored at $0^{\circ} \mathrm{C}$. These antisera were of high avidity, producing visible and compact agglutination within a few seconds. The free-cell count usually was less than 30,000 per $\mathrm{mm}^{3}$ but up to 50,000 was considered satisfactory.

The above mentioned anomalies in our cellsurvival results were periodic increases in the number of unagglutinable cells, a condition which should not have existed provided that the recipient's free-cell count remained constant and the transfused cells were being destroyed continuously. That the increases were not attributable to errors in counting or to alteration in the antiserum was ruled out by repetition of the counts with several lots of the antiserum. Some of the tests were repeated as many as 12 times with consistent results ; others were checked by both authors. In several instances the deviations in the survival counts followed a steady course over a period of 2 or 3 weeks and exhibited a periodicity which was inexplicable. That some erythrocytes were being sequestered from the circulation and released again periodically was hardly tenable. As other investigators $(3,15)$ in similar studies had not encountered the same type or degree of irregularity, it was decided to investigate further into the cause of the phenomenon. Attention was directed first to ascertaining the constancy of the free-cell count and secondly to the influence of the titre and avidity of the antiserum on the completeness of agglutination.

Discussion of the more theoretical aspects of agglutination will be reserved for a later publication. For a survey of the literature relevant to the present study the reader is referred to recent reviews $(16,18,19)$ and to papers by Eagle $(20,21)$, Duncan (22) and Kendall (23).
Whatever the mechanism of agglutination may be, authorities are agreed that the phenomenon involves 2 main stages, namely; (1) the combination of the antigen (agglutinogen) with the antibody (agglutinin) and (2) aggregation of the sensitized cells. Sensitization is known to occur very rapidly while aggregation is a slower process. Eagle (21) and others have shown that mechanical agitation accelerates the rate of agglutination by increasing the incidence of collision of the cells. The process is very rapid at first but decreases logarithmically with time. It may be brought about more rapidly and firmly with the aid of centrifugation. Thus the titre of an antiserum, when determined with centrifugation is from 6 to 10 times that without the treatment. $U p$ to a point agglutination increases with the concentration of agglutinin. Very potent antisera may not produce agglutination or may not give a maximum reaction until diluted. This upper zone of inhibition is usually called the "prozone" to distinguish it from the lower zone, the "postzone" where aggregation of cells is diminished due to dilution of the antibody. The mechanism of prozone inhibition is not fully understood although considerable light has been thrown upon the subject by the studies of Jones and Orcutt (24).

The inadequacy of the ordinary titre method for characterizing the potency of an antiserum has been stressed by numerous authors. Obviously the titre, expressed as a number, merely gives a rough and comparative idea of the agglutinin concentration of the original material. For the purposes of the clinical laboratory, however, the method is valuable particularly for determining the point of optimal proportion of antigen and antibody, i.e., the dilution which produces most rapid agglutination. With moderately strong or weak serum, the maximum rate of agglutination is obtained with the undiluted material. As erythrocytes of different individuals of the same blood group vary considerably in properties, the titre of a given serum and the concentrations of optimum proportion may vary with the blood tested.

In the present study the authors have sought an answer to the following questions :

(1) Can the free-cell count be abolished by careful adjustment of the antiserum concentration and by control of conditions of the reaction? 
(2) What is the normal variation in the freecell count?

(3) To what degree is incomplete agglutination of red cells influenced by the following factors :

(a) Too rapid agglutination and insufficient time for completion of the reaction.

(b) Insufficient antibody.

(c) Under-sensitization of cells due to deficiency in antigen content, or to age.

\section{EXPERIMENTAL}

In 1944 the present authors modified their agglutination technique by introducing centrifugation, thus reducing the time of the procedure to about one-third. Also, with the increased availability of highly potent anti-A and anti-B sera a change was made to the $\mathrm{O}, \mathrm{A}$, and $\mathrm{B}$ blood groups in preference to the $\mathrm{M}$ and $\mathrm{N}$ types.

\section{METHODS}

\section{Selection of antiserum}

In selecting an antiserum for an experiment an ordinary titre series is set up for each serum to be tested using the saline-washed red cells of the prospective recipient. With the aid of a microscope the particular dilution in the series which gives the most complete agglutination is ascertained. This concentration may not be the one which produces the most rapid agglutination or the most compact cell sediment. Having selected the optimum serum concentration for completeness of reaction, a larger quantity of the particular dilution is prepared and dispensed aseptically into small tubes which then are stoppered and stored at $0^{\circ} \mathrm{C}$. Prior to use, each tube is permitted to come to room temperature and is inverted several times to ensure uniformity of the contents.

Very potent anti-A or anti-B sera, particularly those prepared by concentrating the globulin fraction, frequently develop a surface precipitate of lipid when stored at $0^{\circ} \mathrm{C}$. or after having been frozen. Unless removed, this material may prove a source of much annoyance and confusion during cell counting since many of the particles are about the size of the erythrocytes. One of the authors (D. E. O.) has found that the lipid can easily be removed by keeping the serum in a centrifuge tube in the cold for a few days and then cautiously overlaying the surface with physiological saline followed by centrifugation at high speed. If the saline is applied slowly with a fine capillary pipette, no mixing with the serum will occur and, after centrifuging, the saline layer, on the surface of which the lipid will have collected, can be removed by aspiration through a capillary tube.

\section{Collection of blood samples}

Prior to transfusion, and periodically thereafter, blood samples are taken from an antecubital vein of the re- cipient. Approximately $10 \mathrm{ml}$. are delivered into a graduated centrifuge tube containing $1 \mathrm{ml}$. of sterile sodium citrate solution ( 3.2 per cent). The tube is stoppered and inverted gently several times. By emptying the syringe against the wall of the tube and by using gentle mixing methods excessive frothing of the sample can be avoided. Foam may be collapsed by touching it with a fine wire or needle the mere tip of which has been dipped into caprylic alcohol. The total volume of the specimen is recorded to obtain the dilution factor. The hemoglobin concentration of the specimen is determined with a photoelectric colorimeter, and the hematocrit, using the Wintrobe tube. A total red-cell count is performed on the pretransfusion specimen.

\section{Agglutination procedure}

Blood samples, if refrigerated, are permitted to come to room temperature. The red cells are suspended by gently and repeatedly inverting the tube for about 1 minute. Another light mixing is performed immediately before pipetting.

Blood is drawn up to the 0.5 mark in a white-cell pipette which is then filled to the 11 mark with sodium chloride solution ( 0.9 per cent). After the pipette is shaken for a few seconds, it is emptied into a serological tube $(10 \times 75 \mathrm{~mm}$. $)$.

The tube is shaken a few times, and the cell suspension is drawn up to the 1.0 mark in a dry white-cell pipette. The latter is then filled with the agglutinating serum. After the pipette is shaken vigorously for a few seconds, the contents are transferred to a serological tube and centrifuged in an electric table centrifuge at 1500 r.p.m., the machine being turned off automatically at the end of 2 minutes.

The sedimented red cells are dispersed by flicking the tube sharply several times by hand and shaking for an additional 45 minutes on an electric shaker ${ }^{1}$ at 176 vibrations per minute. (The table of the shaker in our laboratory is covered with a 2 -inch slab of fiberglass to insulate the specimens from the heat of the motor.)

Finally, the tube is flicked sharply to suspend the cell sediment, the larger clumps are permitted to settle for a couple of seconds, and a sample of the supernatant fluid is transferred to the hemocytometer by means of a whitecell pipette filled to the 1.0 mark. Counts are made in duplicate and usually agree within 10 per cent.

The free-cell counts are calculated to the number per cubic millimeter of uncitrated blood. With experimental mixtures of $\mathrm{O}$ and $\mathrm{A}$ erythrocytes or $\mathrm{OM}$ and $\mathrm{ON}$ in the proportion of $1: 30$, the lesser component can be determined by selective agglutination within 5 per cent.

\section{Transfusion procedure}

In the majority of our red-cell survival experiments since 1944, the practice has been to determine the blood volume of the recipient prior to transfusion and to determine accurately the quantity of blood administered by

1 No. 3623 rotating apparatus, obtainable from A. H. Thomas Company, Philadelphia. 
weighing the container before and after the transfusion. The hemoglobin, hematocrit and total red-cell count also are determined on a sample taken from the bottle immediately before the experiment. The number of donor cells per $\mathrm{mm} .^{3}$ of the recipient's blood immediately after transfusion, therefore, can be quite accurately calculated.

If the number of cells found is considerably less than the theoretical number, as is often the case when preserved blood is administered, the discrepancy is assumed to represent the number of the donor's erythrocytes eliminated by the recipient during the transfusion.

The volume of citrated blood administered in our experiments formerly was $450 \mathrm{ml}$., but since 1944 has usually been about $200 \mathrm{ml}$.

\section{RESULTS}

\section{Influence of agitation on the rate of agglutina- tion}

The rate of combination of antigen with antibody is known to be extremely rapid. Hence, as numerous workers have shown, the accelerating effect of various modes of agitation and sedimentation on the rate of agglutination is due chiefly to increasing the incidence of contact between the sensitized cells. The size and shape of the container also may influence the rate especially if shaking is the mode of agitation.

Figure 1 illustrates the influence of the rate of horizontal shaking on the completeness of agglutination of erythrocytes at the end of 90 minutes with our apparatus. The unagglutinated-cell count is expressed as the number of free cells observed in the entire field of the hemocytometer, i.e., in $0.9 \mathrm{~mm}^{3}$ of cell suspension. The effect of agitation above 190 vibrations per minute could not be determined with our facilities, but presumably a maximum eventually would be reached beyond which agglutination would be less complete and the damaging effect of the shaking would become a serious factor. Experiments with higher, but unknown, rates of shaking invariably have revealed considerable hemolysis. The results of shaking also vary somewhat with the blood, the antiserum, and the mode of agitation.

Agglutination may be accelerated greatly by an initial light packing of the cells by centrifugation. Figure 2 gives a comparison of the degrees of agglutination with and without centrifuging and at 2 rates of shaking. It will be observed from curve D that centrifugation, followed by shaking for 30 minutes, produces as complete agglutination as does shaking alone at 176 vibrations per minute at the end of 6 hours. Attempts to reduce the unagglutinated-cell count by agitation for more than 6 hours invariably resulted in visible hemolysis. Centrifuging also tends to damage red cells, and, if too prolonged or too rapid, will result in early hemolysis on subsequent shaking.

\section{Influence of strength of antiserum}

In determining the agglutinating titre of a strong antiserum by the ordinary method of progressive dilution, one tube in the series usually shows more rapid agglutination than those preceding or following it. This particular dilution represents, or approximates, the concentration of optimum proportion of the antigen and antibody as far as rate of agglutination is concerned. If aggregation of the

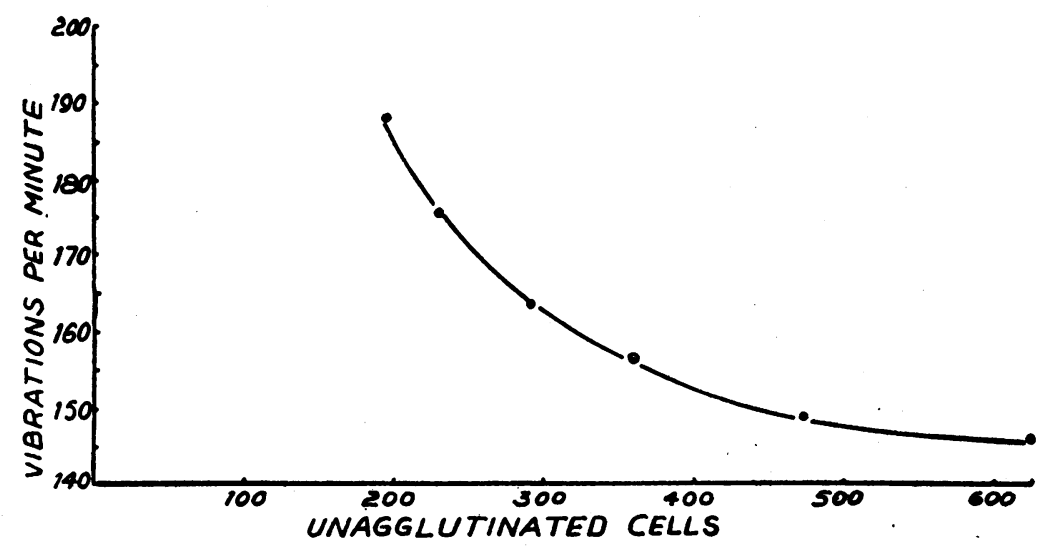

Fig. 1. Influence of the Rate of Shaking on the Completeness of Agglutination 


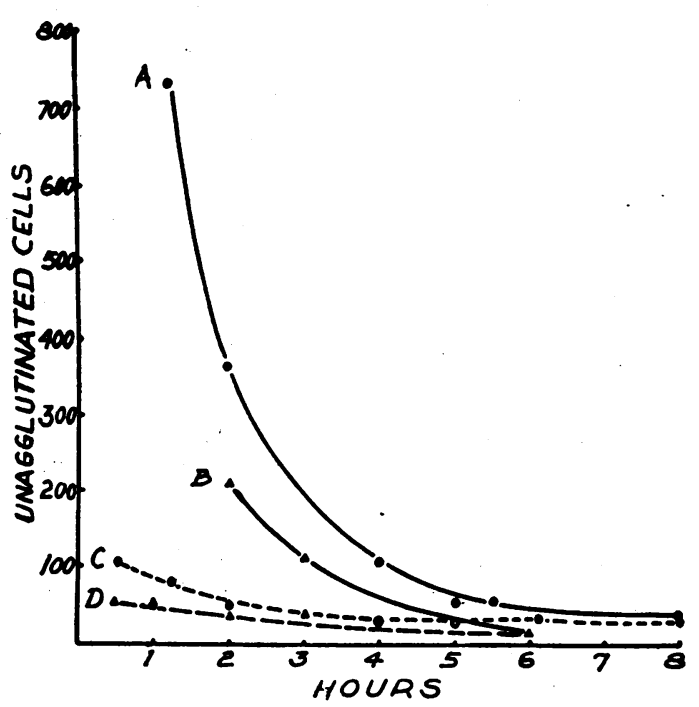

Fig. 2. Progress of Agglutination at Two Rates of Shaking With and Without an Initial Light CenTRIFUGATION

Curves $A$ and $C, 146$ vibrations per minute; curves $B$ and $D, 176$ per minute.

red cells takes the form of a single, compact clump, one easily may be misled into assuming that agglutination is complete. On examination under the microscope, however, a surprisingly large number of unagglutinated cells may be observed. The concentration which affords the most rapid agglutination, therefore, may not produce the most complete reaction. This is true especially of antisera of marked avidity, notably anti-M and anti-N sera, which, even when diluted many times, may produce visible and compact agglutination within a few seconds. In preparing an antiserum for selective agglutination, therefore, it is essential to ascertain the relative concentration which produces the most complete aggregation of cells. This concentration usually is in the neighborhood of that which produces most rapid agglutination. With serum of only moderate potency, the maximum is obtained with the undiluted material.

The relation between the strength of the antiserum and the completeness of agglutination or the free-cell count is illustrated in Figures 3 to 9 inclusive. To facilitate comparison, the data are presented in the form of graphs. In doing so the authors wish to direct attention to the inconsistency in the results with different dilutions of serum rather than to imply that the fluctuations are due to variation in the properties of the erythrocytes or the antiserum, although either, or both the latter conceivably may occur.

(a) CONSTANCY OF THE UNAGgLUtiNABLE-CELL COUNT

Figures 3 to 6 inclusive illustrate the fluctuations in the free-cell count with various dilutions of antiserum and in different individuals, over a period of 2 months. The results are expressed as thousands of cells per cubic millimeter of the recipient's blood. Attention is directed to the magnitude of the fluctuations in Figure 6. The counts were done in duplicate.

The variability of the free-cell count with the lower concentrations of antiserum is pronounced. With serum of marked avidity, e.g., anti-M and anti- $\mathrm{N}$, the rapidity, firmness, and compactness of agglutination may easily mislead one into thinking that agglutination is complete.

The stronger concentrations, on the other hand, produce a low free-cell count, which, in the case of the optimum concentration, remains practically constant within the counting error. Occasionally we have found that the recipient's free-cell count, after the donor's cells have disappeared from the circulation, is slightly higher than before the transfusion. In these cases the higher count has been used in calculating the results. For the purpose of the redcell survival test, provided a strong serum is used, the unagglutinable-cell count of the recipient may be assumed to remain constant.

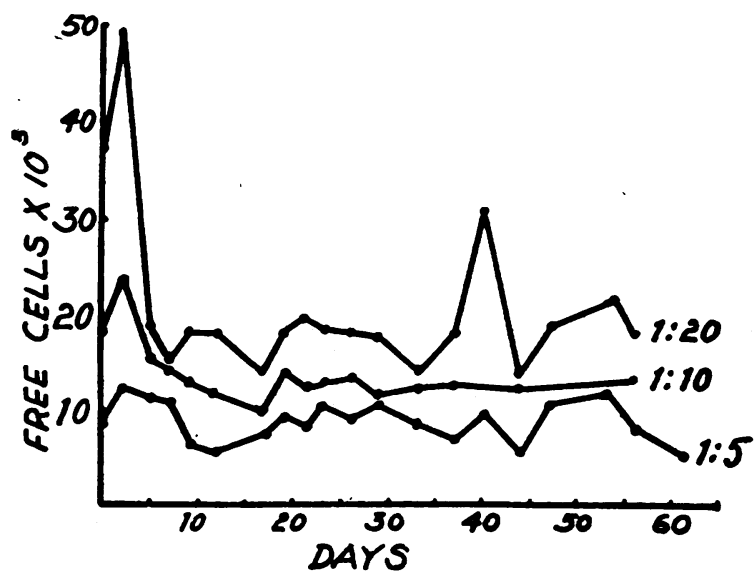

Fig. 3. Variation in the Free-cell Count of a Group-B Subject with Potent Anti-B Serum (Titre 5,000) Diluted 5, 10, And 20 Times, Respectively 


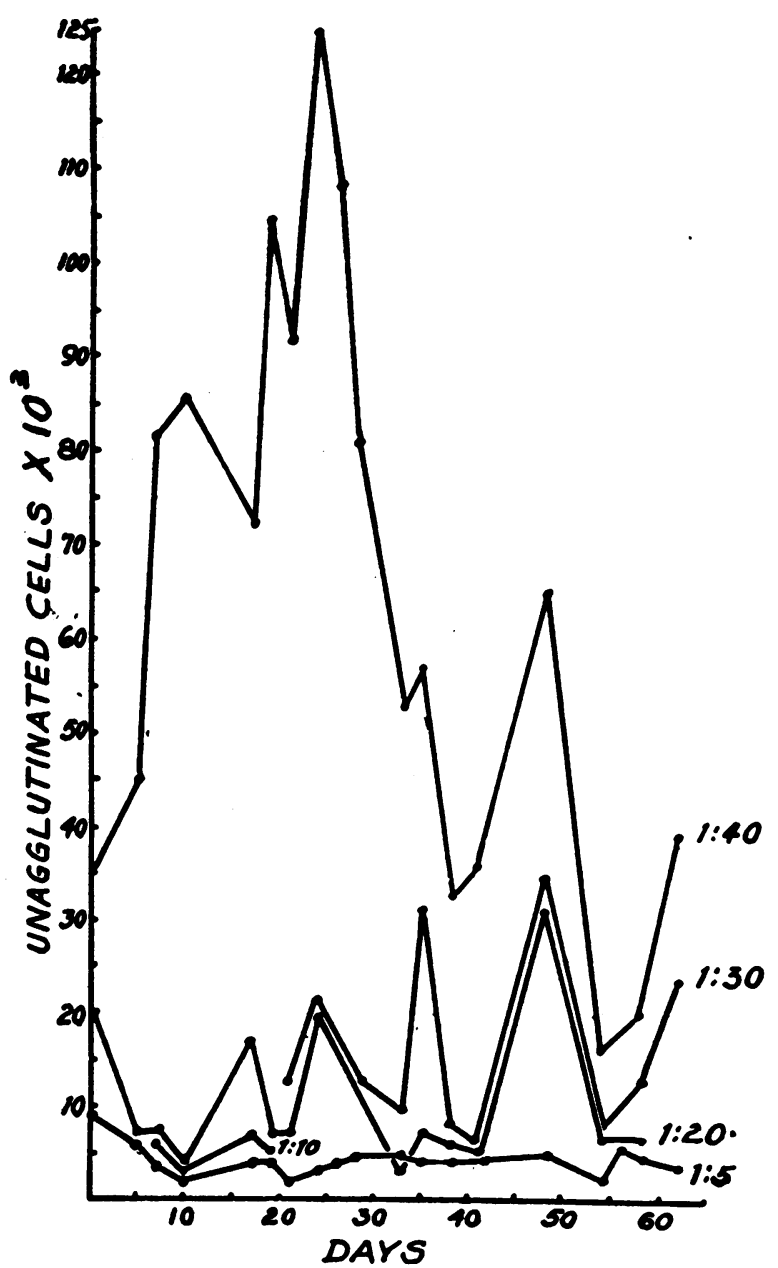

Fig. 4. Variation in the Free-cell Count of a Group-A Subject with a Potent Anti-A Serum (Titre 5,000) Diluted 5, 10, 20, 30, ANd 40 Times, ReSPECTIVELY

(b) AGgLUTINABILITY OF PRESERVED ERYTH-
ROCYTES

It was anticipated that if the fluctuations observed in the agglutinability of erythrocytes with weak sera are due to changes in the agglutinogens on the cell membrane, the agglutinability of the cells might become increasingly erratic with storage.

In Figure 7, the curves " $A$ " represent periodic free-cell counts on blood (group $A_{1} M R h_{1} R h_{2}$ ) preserved in citrate-dextrose solution at $5^{\circ} \mathrm{C}$. over a period of 50 days ; " $B$ ", the counts on fresh blood from the same donor. Here again the stronger serum (anti-A diluted 1:5) gave more constant results than the weaker lot (diluted
$1: 10)$. It is noteworthy also that under optimum conditions of preservation the agglutinability of the stored erythrocytes does not differ from that of the fresh blood. The counts are expressed as the number of free cells in the hemocytometer field in order to accentuate the fluctuations. (The factor for converting the count to cells per $\mathrm{mm}^{3}$ is approximately 270.) Since many of the erythrocytes, by the fiftieth day of storage, become nonfunctional (at least 50 per cent of the cells), it appears that agglutinability is not greatly impaired by the loss of viability provided conditions of preservation are favorable.

The curve in Figure 8 illustrates the behavior of the free-cell count in a sample of preserved blood of group OMRh using a potent anti-M serum diluted 20 times. The variation is typical of that observed with diluted antisera even in fresh blood. There is no evidence in this and in similar experiments that the reactivity of the $M$ and $N$ agglu-

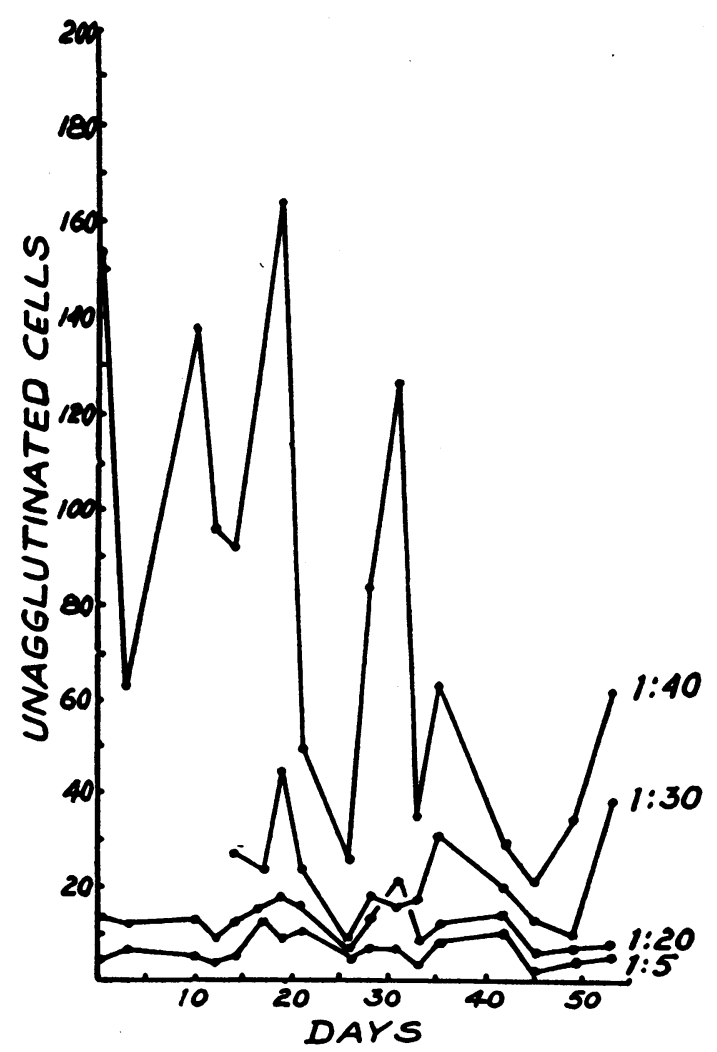

Fig. 5. Fluctuation in Free-cell Count of a Group-A Individual with Potent Anti-A Serum (Titre 5,000) Diluted 5, 20, 30, and 40 Times, ReSPECTIVELY 
tinogens is impaired during storage under optimum conditions at least up to 6 weeks.

\section{Estimation of transfused erythrocytes}

In view of certain anomalies observed up to 1944 in our experiments on mental patients it was thought advisable to perform a few cell-survival tests on normal subjects. Accordingly $200 \mathrm{ml}$. of fresh citrated blood of a donor group $\mathrm{ONRh}_{1}$ was administered to each of 2 recipients and counts were followed daily for about 60 days. Figure 9 illustrates the disappearance of the donor's cells from the circulation of a recipient, group $\mathrm{OMNRh}_{2}$, as determined with anti-M serum (titre 64), and Figure 10, the curve for the second recipient, group $A M R h_{1} \mathrm{Rh}_{2}$, as determined simultaneously with anti-A (dotted curve) and anti-M sera. The gaps in the curves were occasioned by a holiday. It is noteworthy that despite the ir-

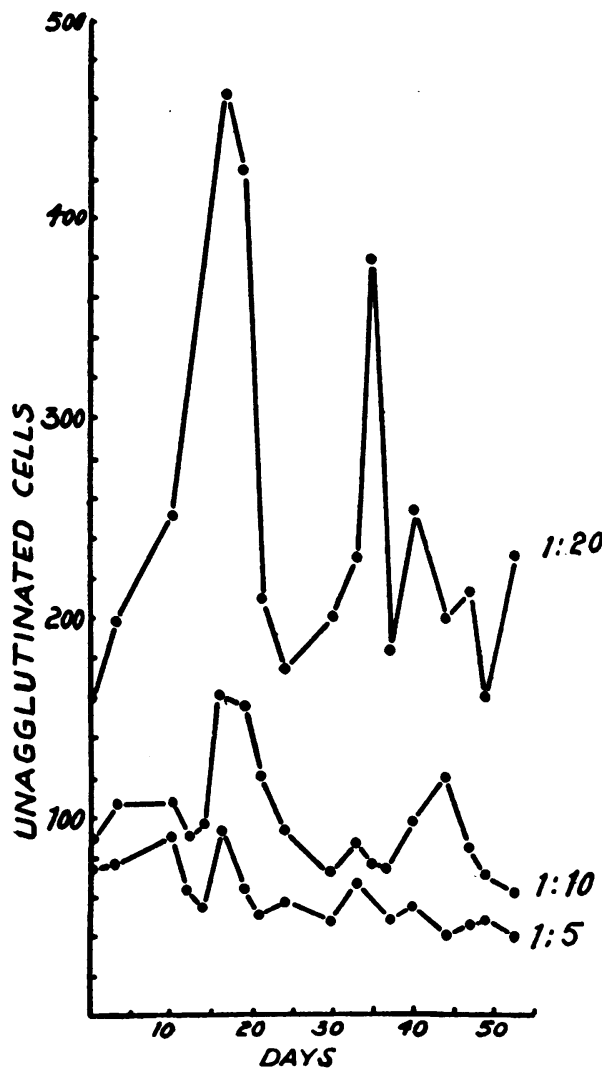

Fig. 6. Fluctuation in Free-cell Count of a Group-A Individual with a Potent Anti-A Serum (Titre 5,000) Diluted 5, 10, and 20 Times, RespecTIVELY
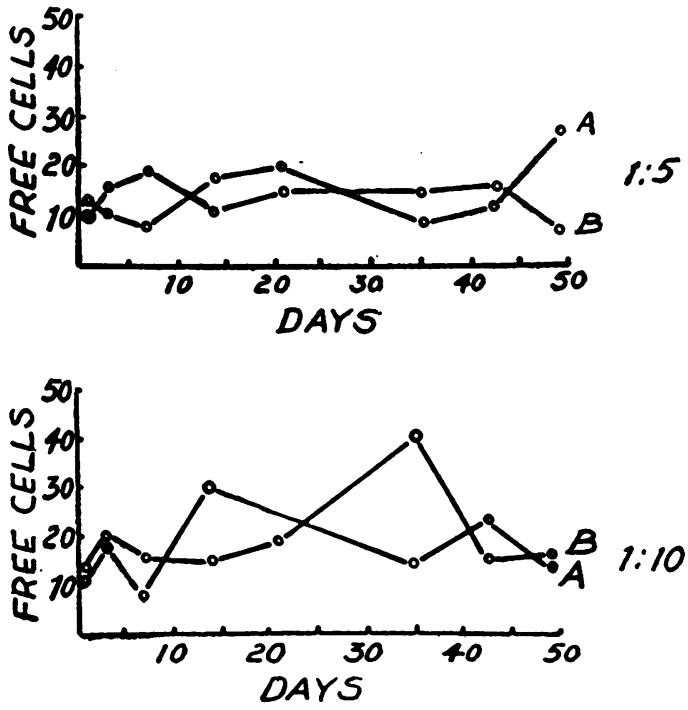

Fig. 7. Comparative Variation in the Free-cell Count in Preserved and Fresh Blood of a Group-A Subject Using Potent Anti-A Serum (Titre 5,000) Diluted 5 and 10 Times, Respectively

Curves A represent preserved blood and curves B, fresh blood.

regularities due to the use of diluted sera, the course of the red-cell elimination is quite accurately indicated. With diluted antisera, cell counts should be performed at least weekly in order to be able to correct for irregularities.

Figure 11 represents a transfusion series, performed in June 1944, in which $150 \mathrm{ml}$. of blood from 1 donor of group $\mathrm{ON}$, was administered to each of 4 recipients. The first received a fresh specimen and the others, in turn, samples that had been preserved in citrate-dextrose at $5^{\circ} \mathrm{C}$. for 12 , 22 , and 40 days, respectively. The free-cell counts of the recipients are included in Table $\mathrm{I}$.

The rapid elimination of non-viable red cells within 3 to 6 hours after transfusion is indicated in curves B, C, D. In our experience, with blood stored for more than 3 weeks, there usually is indication of a partial elimination of the non-viable cells even during the period of the transfusion $(200 \mathrm{ml}$.). The 100 per cent count in the posttransfusion sample in recipient $D$, therefore, is exceptional. It is noteworthy that a rapid elimination of erythrocytes always occurs with preserved blood within a few hours after transfusion, the loss amounting roughly to 1 per cent of the cells per day of storage (or more if conditions of preserva- 


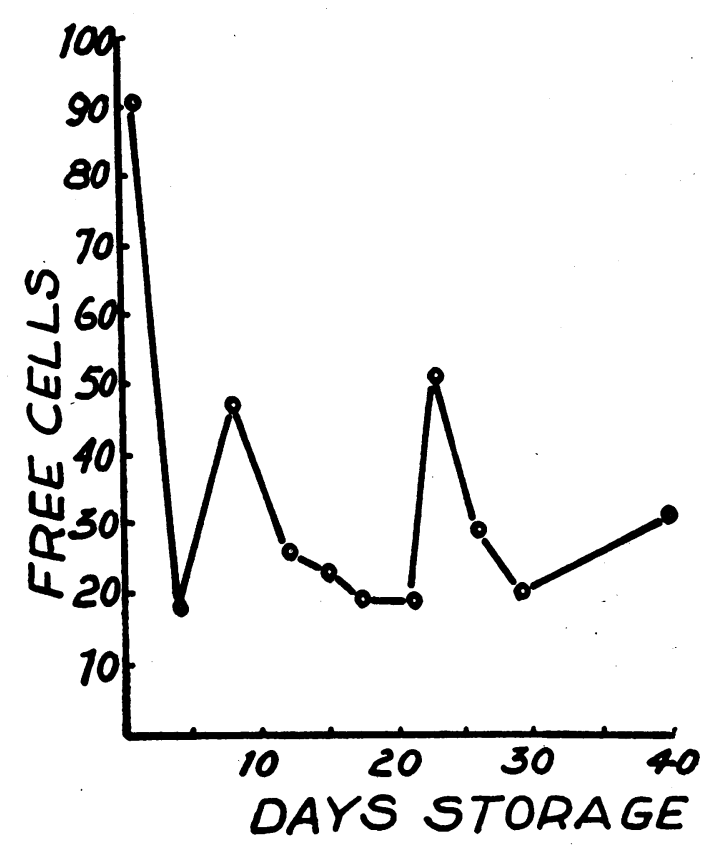

Fig. 8. Fluctuation in the Free-cell Count of a Preserved Blood Sample, Group-AM, Using an Avid, but Diluted, anti-M Serum

tion are not optimum). With strong antisera the survival curves, for the most part, are free from gross irregularities.

One type of anomaly which the writers have encountered occasionally in exaggerated form with potent anti-M and anti-N, and even with

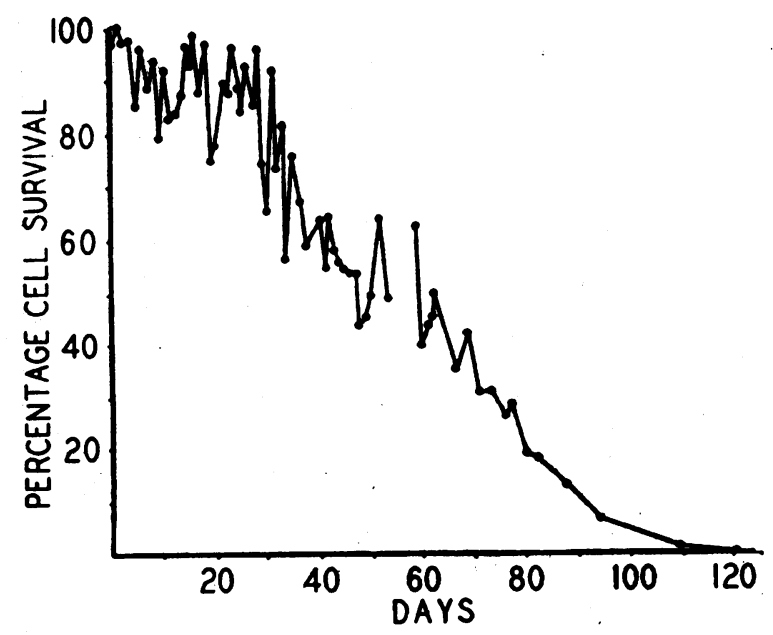

Fig. 9. Elimination of the Erythrocytes of a Group-ON Donor from the Circulation of a GroupOMN Recipient Using Diluted Anti-M AgglutinatING SERUM

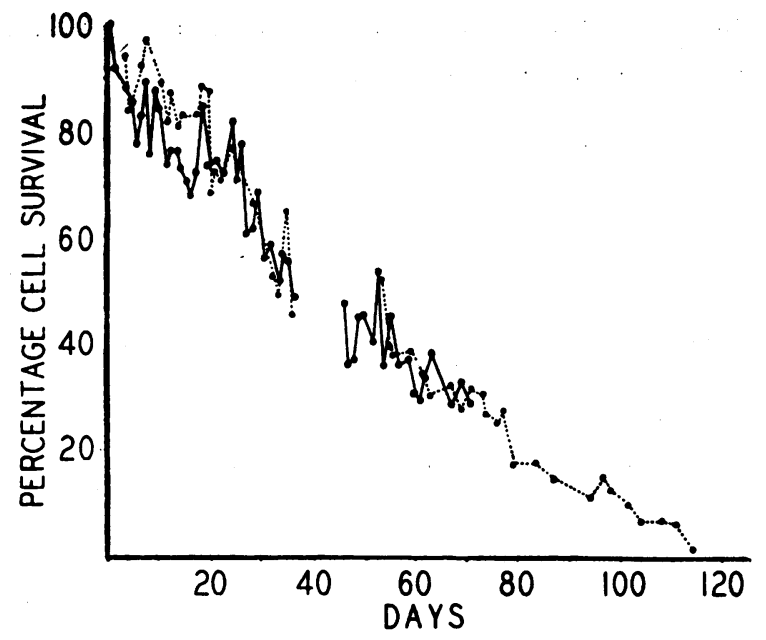

Fig. 10. Elimination of the ERythrocytes of a Group-ON Donor from the Circulation of a GroupAM Recipient, Counts Being Made Simultaneously with Anti-A (Dotted Curve) and Anti-M Sera

strong anti-A serum, is illustrated by the large discontinuities in Figures 12, 13, and 14. The particulars of these experiments are given in Table II.

It will be observed that the free-cell counts of one of the recipients of type $\mathrm{M}$ differs considerably from the others. The same anti-M serum was used in each case. It is noteworthy also that the large deviation in Figure 13 was given by the recipient with the lower free-cell count. The irregularities in the 3 figures exhibit a remarkably smooth course, a circumstance which makes explanation difficult on the basis of technical errors.

\section{DISCUSSION}

Of the various factors that may influence the accuracy of selective agglutination, the strength of the antiserum is of major concern. As yet there is no practical method for characterizing a serum quantitatively as to its avidity and agglutinin content. The titre method of estimating potency gives only comparative values. Nevertheless, it is valuable for testing the strength of the serum for typ-

\begin{tabular}{c|c|c|c}
\multicolumn{4}{c}{ TABLE I } \\
\hline Recipient & Group & Antiserum & Free-cell count \\
\hline & & & per $m m .^{3}$ \\
A & OMN & anti-M & 4,000 \\
B & AMN & anti-M & 4,000 \\
C & OMN & anti-M & 5,000 \\
D & AMN & anti-M & 7,000 \\
\hline
\end{tabular}




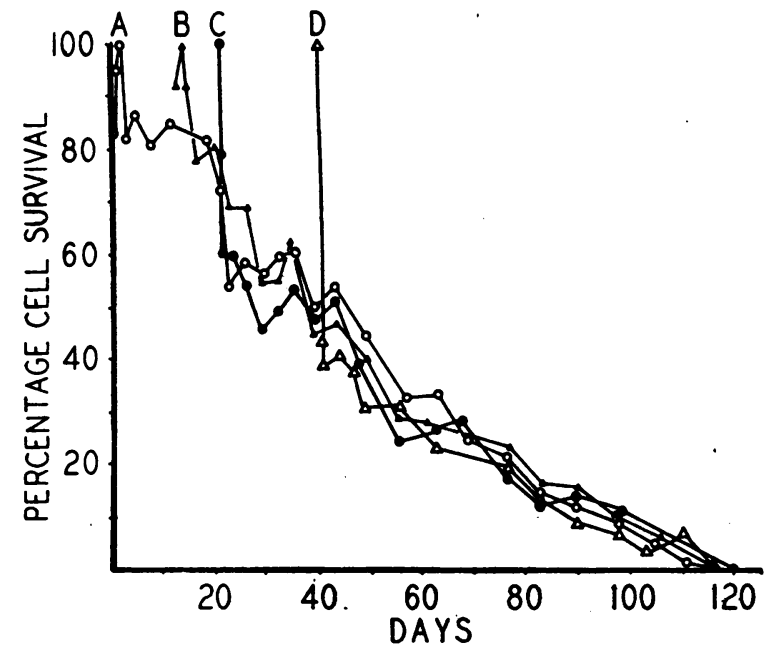

Fig. 11. Elimination of the ERythrocytes of a Donor, Blood Group-ON, From the Circulation of 4 Recipients, Using a Strong Anti-M Agglutinating Serum. (See Table I.)

ing purposes and for estimating the optimum concentration of red cells and antiserum.

The term "optimum," as applied to agglutination, usually implies rapidity of reaction rather than completeness. The point of optimum proportion in the titre series, for example, is the concentration of cells and serum which produces the most rapid or most compact agglutination. As mentioned previously, this concentration does not necessarily produce maximum agglutination and, with sera of marked avidity, e.g., anti-M and anti$\mathrm{N}$, the number of unagglutinable cells may be relatively large. Rapidity, compactness and firmness of agglutination, therefore, are not reliable criteria of the completeness of the reaction.

As shown in the foregoing graphs (Figures 3

TABLE II

\begin{tabular}{|c|c|c|c|c|c|}
\hline Figure & Donor & Recipient & $\begin{array}{c}\text { Storage } \\
\text { period }\end{array}$ & $\begin{array}{c}\text { Anti- } \\
\text { serum } \\
\text { : }\end{array}$ & $\begin{array}{l}\text { Recipi- } \\
\text { ent's } \\
\text { free-cell } \\
\text { count }\end{array}$ \\
\hline 12 & ON & $\begin{array}{l}\mathrm{OMRh}_{1} \\
\mathrm{OMRh}_{2}\end{array}$ & $\begin{array}{c}\text { days } \\
\text { fresh } \\
25\end{array}$ & anti-M & $\begin{array}{r}\text { per } m m .2 \\
4,000 \\
3,000\end{array}$ \\
\hline 13 & $\begin{array}{l}\text { Pooled } \\
\text { ONRh }^{+} \\
\text {ONRh }_{1}\end{array}$ & $\begin{array}{l}\mathrm{OMRh}_{1} \mathrm{Rh}_{2} \\
\mathrm{OMRh}_{1}\end{array}$ & $\begin{array}{l}22 \\
22\end{array}$ & anti-M & $\begin{array}{r}18,000 \\
5,000\end{array}$ \\
\hline 14 & $\mathrm{OMRh}_{1}$ & $\mathrm{ONRh}_{2}$ & 21 & anti-N & 42,300 \\
\hline
\end{tabular}

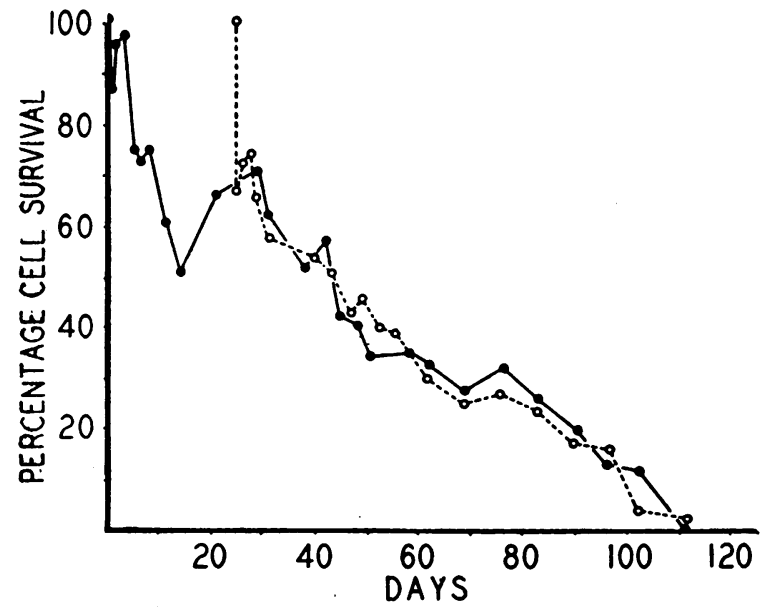

Fig. 12. Elimination of the Erythrocytes of a Fresh and a Preserved Blood Sample from a GroupON Donor, from the Circulation of 2 Group-OM ReCipients. (See TAble II.)

to 9) antisera, particularly diluted sera, which give a high free-cell count, usually display marked variability. It is noteworthy, however, that the free-cell count even with undiluted sera may vary with different bloods. Thus, in Table II, the freecell count with one individual was 5,000 and with another, was 18,000 . Occasionaly also, one meets with a potent serum which gives a constant freecell count with one person and a variable count with another. There are instances when dilution of the serum reduces the free-cell count, e.g., when the serum concentration is above the optimum. In general, however, one can say that a high concentration of agglutinin is necessary for maximum and consistent agglutination, and that dilution of the serum tends to increase the number of unagglutinated cells and the variation in the counts.

The reason for the high free-cell count with markedly avid antisera is not clear. Anti-M and anti-N sera, like many heterologous immune sera, produce a very rapid and firm type of agglutination. It is significant that the unagglutinated cells apparently do not adhere to the agglutinates already formed nor are they occluded to any considerable extent among the rapidly aggregating masses. The failure of many of the cells to become agglutinated cannot be attributed to a lack of antibody. Centrifugation will cause further aggregation but not to the extent one would expect with fully sensitized cells. 


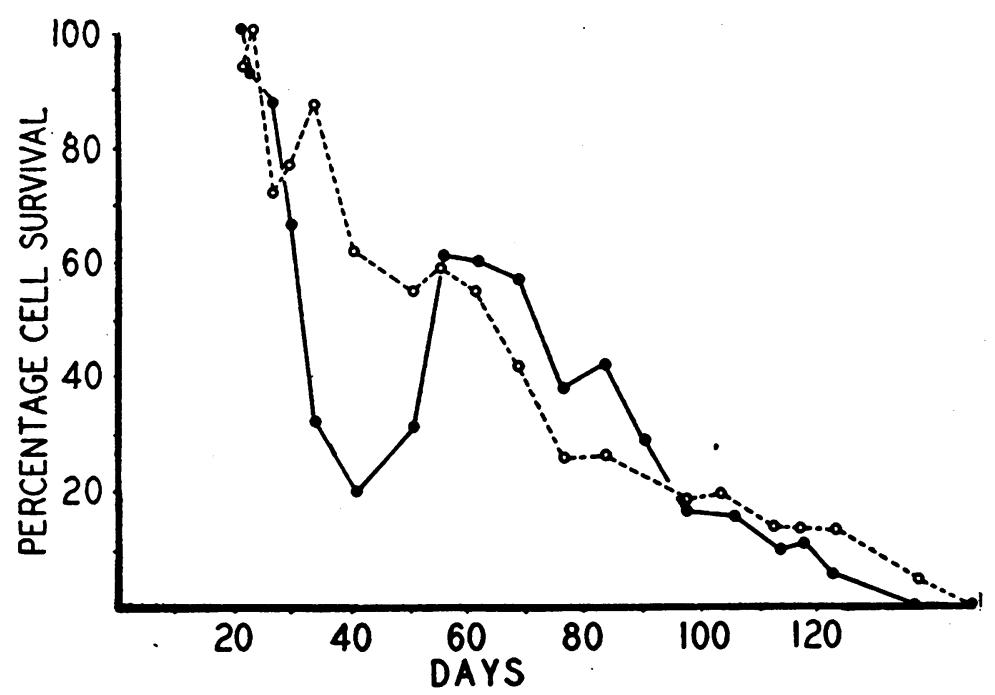

Fig. 13. Elimination of Preserved Erythrocytes of 2 Group-ON Donors (Pooled Sample) from the Circulation of 2 Group-OM Recipients. (See TAble II.)

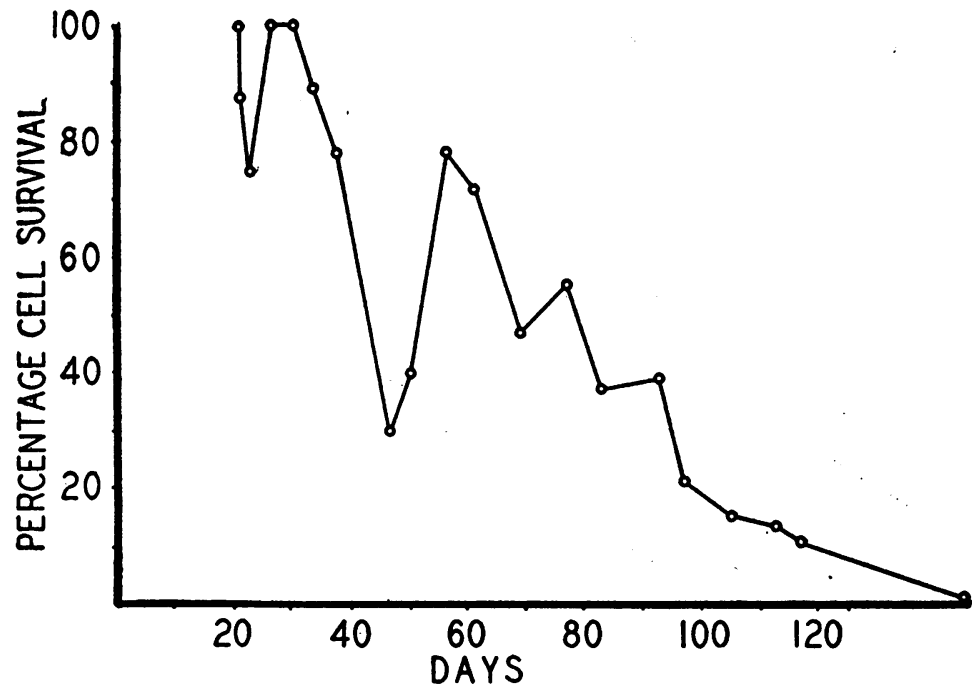

Fig. 14. Elimination of Preserved Erythrocytes of a Group-OM Donor from the Circulation of a Group-ON Recipient. (See Table II.)

On first thought, the failure of some cells to be agglutinated with strong antiserum suggests that the red-cell population possibly may be made up of cells ranging in agglutinability from extremely to feebly reactive, and that, while the latter may be loosely agglutinated by centrifuging, like weak $\mathrm{Rh}$ agglutinates, they may be dispersed again by agitation. Such a hypothesis would imply that the socalled "unagglutinable" cells may be deficient in the content, distribution, or quality of their ag- glutinogens due perhaps to imperfect formation.

In opposition to this reasoning, one may point out that the addition of a strong antiserum to the residual free cells after agglutination with a weak antiserum, does not effect as complete agglutination as when the strong serum is applied directly to fresh cells. Weak serum may give rise to agglutinates in the form of doublets, or chains which can be broken by shaking. Addition of stronger antiserum does not consolidate the aggregates into 
a compact mass. It is significant also that 2 volumes of half-strength antiserum are not necessarily equivalent in agglutinating strength and effect to 1 volume of undiluted serum for a given volume of cell suspension even when centrifugation is employed. On the basis of these observations; one is inclined to attribute the differences in free-cell count and agglutinability to a reversible change in the state of the agglutinins or other components of the system with dilution and changes in temperature.

The variability in the counts with diluted antiserum is of considerable interest since the fluctuations are not due to systematic errors. In the writers' experience the free-cell counts are likely to vary from day to day but they may be quite consistent on any day.

While the use of diluted, though avid, anti-M and anti-N sera explains some of the sharp irregularities observed in our earlier study, the larger and more regular deviations of the type illustrated in Figures 12, 13, and 14 are not so easily explained. Our former interpretation, that perhaps some of the donor's erythrocytes are sequestered from the recipient's circulation and released later, has been abandoned. The deviations doubtless are connected in some way with reversible changes in the properties of the antiserum, or possibly to reversible changes in the reactivity of the recipient's cells. It is evident from Table II that they are not attributable to the use of weak antiserum, nor are they confined to the use of the $\mathrm{M}$ and $\mathrm{N}$ blood types. Other factors such as agitation, temperature, salt concentration, and $\mathrm{pH}$ have been ruled out. The study of this phenomenon is being continued.

Highly potent anti-A and anti-B sera being easy to prepare, or being readily obtainable the writers recommend for selective agglutination, sera which give a free-cell count not exceeding 10,000 per $\mathrm{mm}^{3}$ The lowest free counts obtained in our studies. were about 2,500 . With strong serum the variation in the free-cell count is usually within 5,000 per $\mathrm{mm}^{3}$ Irregularities in the cell-survival curve become noticeable when the free-count exceeds 15,000 , and, above 40,000 , fluctuations may occur ranging up to 200,000 from day to day. Obviously it is desirable to keep the variation within the limits of error of the technique. With small transfusions, e.g., $200 \mathrm{ml}$., it is especially important to select antisera which will reduce the freecount to a minimum.

\section{CONCLUSIONS}

From the evidence submitted and additional work not reported herein, it appears that there is no routine method for achieving complete agglutination of erythrocytes and that such an attainment is not possible when agitation is involved. In some experiments, however, the unagglutinablecell count has been reduced to as low as 2,500 per $\mathrm{mm} .^{3}$ With strong agglutinating serum the freecell count of the individual remains practically constant for the majority of persons, especially of group $A_{1}$. The sharp irregularities observed in the cell-survival curves in an earlier study are attributable to the use of diluted anti-M and anti-N sera. The larger and more regular type of deviation, however, still remains unexplained; it is doubtless connected with some obscure change in the properties of the anti-serum or of the recipient's red cells. These deviations and irregularities do not necessarily vitiate the results of the cellsurvival method. A high degree of accuracy can be obtained in the estimation of survival if the blood volume of the recipient and the number of erythrocytes transfused are accurately known.

\section{SUMMARY}

The presentation concerns the factors that affect the accuracy of the selective-agglutination procedure for estimating the survival of erythrocytes after transfusion. The influence of agitation, centrifugation, and the agglutinin titre of the antiserum on the rate and completeness of agglutination of red cells is discussed. The unagglutinablecell count cannot be eliminated, but it can be reduced to a minimum and practically constant quantity by careful selection of the antiserum. Some of the irregularities observed in an earlier study undoubtedly were due to the use of diluted, though avid, anti-M and anti- $\mathrm{N}$ sera. The larger and more regular deviations, however, are not so easily explained; they appear to be related to reversible changes in the properties of the antiserum or to reversible changes in the properties of the recipient's red cells. If the blood volume of the recipient and the number of red cells transfused 
are accurately known, the progressive elimination of the donor's cells from the circulation of the recipient can be followed with a fairly high degree of accuracy.

\section{ACKNOWLEDGMENTS}

This study is part of an investigation on blood preservation carried on with the financial support of the National Research Council of Canada.

The authors are indebted to Dr. L. K. Diamond for a supply of high-titred anti-A and anti-B serum, and to Dr. A. S. Weiner for anti-M and anti-N sera, and for Rhtyping.

Thanks are due also to Dr. H. Lehmann of the Verdun Protestant Hospital who performed most of the transfusions and collected the blood specimens.

\section{BIBLIOGRAPHY}

1. Ashby, W., The determination of the length of life of transfused blood corpuscles in man. J. Exper. Med., 1919, 29, 267.

2. Schaefer, G., and Wiener, A. S., Limitations in use of preserved blood for transfusions; preliminary report. Quart. Bull. Sea View Hosp., 1939, 5, 17.

3. Wiener, A. S., and Schaefer, G., Limitations in use of preserved blood for transfusion; study of fate of transfused erythrocytes in recipient's circulation. M. Clin. North America, 1940, 24, 705.

4. Mollison, P. L., The survival of transfused erythrocytes in hemolytic disease of the newborn. Arch. Dis. Childh., 1943, 18, 161.

5. Wiener, A. S., and Peters, H. R., Hemolytic reactions following transfusions of blood of the homologous group, with 3 cases in which the same agglutinogen was responsible. Ann. Int. Med., 1940, 13, 2306.

6. Mollison, P. L., and Young, I. M., Survival of transfused erythrocytes of stored blood. Lancet, 1940, $2,420$.

7. Bushby, S. R. M., Kekwick, A., Marriott, H. L., and Whitby, L. E. H., Survival of stored red cells after transfusion. Lancet, 1940, 2, 414.

8. Belk, W. P., and Barnes, B. C., Survival time after transfusion of erythrocytes of citrated human blood stored at $4^{\circ}$ to $6^{\circ}$ centigrade. Am. J. M. Sc., 1941, 201, 838.
9. Denstedt, O. F., Osborne, D. E., Stansfield, H., and Rochlin, I., Survival of preserved erythrocytes after transfusion. Canad. M. A. J., 1943, 48, 477.

10. Wearn, J. T., Warren, S., and Ames, O., Length of life of transfused erythrocytes. Arch. Int. Med., 1922, 29, 527.

11. Maizels, M., and Paterson, J. H., Survival of stored blood after transfusion. Lancet, 1940, 2, 417.

12. Loutit, J. F., Factors influencing preservation of stored red cells. J. Path. \& Bact., 1945, 57, 325.

13. Thalhimer, W., and Taylor, E. S., Transfusion of centrifuged human type $O$ cells resuspended and stored in 10 per cent corn syrup. J. A. M. A., 1945, 127, 1096.

14. Dacie, J. V., and Mollison, P. L., Survival of normal erythrocytes after transfusion to patients with familial haemolytic anaemia (acholuric jaundice). Lancet, 1943, 1, 550.

15. Mollison, P. L., and Young, I. M., On survival of transfused erythrocytes of stored blood. Quart. J. Exper. Physiol., 1941, 30, 313.

16. Wiener, A. S., Blood Groups and Transfusion. Third Edition. Charles C. Thomas, Springfield, Illinois, 1943.

17. Davidsohn, I., and Rosenfeld, I., Preparation of anti$\mathrm{M}$ and anti-N testing fluids. Am. J. Clin. Path., 1939, 9, 397.

18. Landsteiner, K., The Specificity of Serological Reactions. Harvard University Press, Cambridge, Mass., 1945.

19. Boyd, W. C., Fundamentals of Immunology. Interscience Publishers, Inc., N. Y., 1943.

20. Eagle, H., Specific agglutination and precipitation; mechanism of reactions. J. Immunol., 1930, 18, 393.

21. Eagle, H., Specific agglutination and precipitation; velocity of reactions. J. Immunol., 1932, 23, 153.

22. Duncan, J. T., Specific character of stage of aggregation in agglutination and precipitation of antibodyantigen compounds. Brit. J. Exper. Path., 1938, $19,328$.

23. Kendall, F. E., Quantitative relationship between antigen and antibody in precipitin reaction. Ann. New York Acad. Sc., 1942, 43, 85.

24. Jones, F. S., and Orcutt, M., Prozone phenomenon in specific bacterial agglutination. J. Immunol., 1934, $27,215$. 